\title{
Research on the System Simulation of Forest Cutting Arrangement in Giam Siak Kecil Bukit Batu Biosphere Reserve
}

\author{
Arie Afriadi $^{1}$, Agus Dwi Wicaksono ${ }^{2}$, Nailah Firdausiyah ${ }^{3}$ \\ ${ }^{1,2,3}$ Brawijaya University, Urbanand Regional Planning, MT HaryonoNo.167, Malang65145, Indonesia
}

\begin{abstract}
Giam Siak Kecil - Bukit Batu is the largest peat swamp forest in the world as a Biosphere Reserve, even though it has been designated as a biosphere reserve, but deforestation still continues, thereby threatening the preservation of the environment and existing ecosystems inside of. This paper aims to determine the deforestation that occurred in the Giam Siak Kecil - Bukit Batu Bosphere Reserve in the form of land cover distribution, deforestation area, deforestation rate and to build a model of the causes of deforestation in the 1999 - 2019 period. Data used ini this study from Landsat TM 5 images in 1999 and 2009, Landsat OLI 8 images from 2019, Indonesian Earth maps, boundary maps of the Giam Siak Kecil Biosphere Reserve - Bukit Batu, road network maps and population density maps. The method used in this paper uses remote sensing technology and multiple linear regression analysis. The results of the study obtained that the land cover in the Giam Siak Kecil Biosphere Reserve - Bukit Batu contained 8 classes, the area and rate of deforestation within a period of 20 years reached $3099.26 \mathrm{Km}^{2}$ with a deforestation rate of 154.96KM2/year, and the results of deforestation modeling showed that there were 5 variables that have an effect of which 4 variables have a positive effect and 1 variable has a negative effect. The variables that have a positive effect are industrial plantations forest (X1), plantations (X3), bushland (X3), open land (X5) and the variable that has a negative effect is water bodies (X7), with the model equation $Y=-3502564,382+1,257(X 1)$ $+1,963(X 3)+0.611(X 4)+1,343(X 5)-9,494(X 7)$.
\end{abstract}

Keywords: Deforestation, Modeling, Biosphere Reserves, Land Cover

\section{Introduction}

Indonesia is a country with the largest population in the world with an economic growth continues to increase, Indonesia's increasing economic growth does not escape environmental problems that are of concern to the world. One of the international issues of Indonesia's involvement is related to climate change. One of the problems is deforestation [1].

Deforestation in Indonesia has increased every year, recorded from the period 2014 - 2015 to 1.09 million hectares, and at other times in 2015 - 2016 changed to 0.63 million hectares of the total forest area in Indonesia [2]. The highest deforestation rate in Indonesia is on the island of Sumatra, spesifically in Riau Province. Degradation land cover area in Riau Province continues until now. It was recorded that in 1990 the forest cover of Riau Province was $60.22 \%$ of the area of Riau Province and continued to decrease every year to $29.17 \%$ in 2011 [3]. The reduction or deforestation in forest cover also occurred in the Giam Siak Biosphere Reserve - Kecil Bukit Batu area.

Giam Siak Kecil - Bukit Batu is a peat swamp forest designated as a biosphere reserve in the UNESCO Man and the Biosphere Program declaration, in 2009 with an area of $7045.42 \mathrm{Km}^{2}$, the biosphere reserve area includes 2 wildlife reserves, namely the Giam Siak Wildlife Reserve Small and Bukit Batu Wildlife Sanctuary. The basic function of the Giam Siak Kecil - Biosphere Reserve is to Bukit Batu determine a strategic area from the point of view of environmental function and carrying capacity, which aims to maintain and preserve the ecosystem in it [4]. Deforestation of the Giam Siak Kecil Biosphere Reserve Bukit Batu is not avoidable, although it has been designated as a biosphere reserve area, deforestation still occurs, based on the results of research conducted by Sadili, [5], in the period 2010 to 2014, the total forest area in The Giam Siak Kecil Wildlife Sanctuary decreased from 60, 051.27 Ha to $51,167.41 \mathrm{Ha}$, while the area of monocultural plantations dominated by oil palm and rubber and industrial plantation forests continued to increase.

Deforestation that occurs in the Giam Siak Kecil Biosphere Reserve - Bukit Batu can be identified through spatial modeling by looking at the causes of the effect of deforestation on each variable. Deforestation studies that continue to develop are spatial modeling that is construction of a model with variables related to the factors that cause deforestation. The combination of statistical calculations and spatial analysis produces a spatial model of deforestation and provides an overview of the location and distribution of deforestation and the factors that cause deforestation [6]. Knowing this will make it easier to plan for handling deforestation and planning forest areas in the Giam Siak Kecil Biosphere Reserve - Bukit Batu that is more sustainable. Building a spatial model of deforestation by utilizing remote sensing technology and geographic information systems. The role of data from remote sensing technology and geographic information systems continues to grow until now, the development of data from remote sensing technology is presented more fully, can be obtained in a short time, repeated and has a very wide scope [7].

The purpose of this study was to determine the distribution of land cover, the extent of deforestation, the rate of deforestation and to build a model for the causes of deforestation in the Giam Siak Kecil Biosphere Reserve Bukit Batu in the 1999 - 2019 period. 


\section{Study Area}

This research was conducted in the Giam Siak Kecil Biosphere Reserve - Bukit Batu with an area of 7045.42 $\mathrm{Km}^{2}$. The Giam Siak Kecil - Bukit Batu Biosphere Reserve area is included in 3 city district administrations in Riau Province including Bengkalis Regency, Siak Regency and Dumai City.

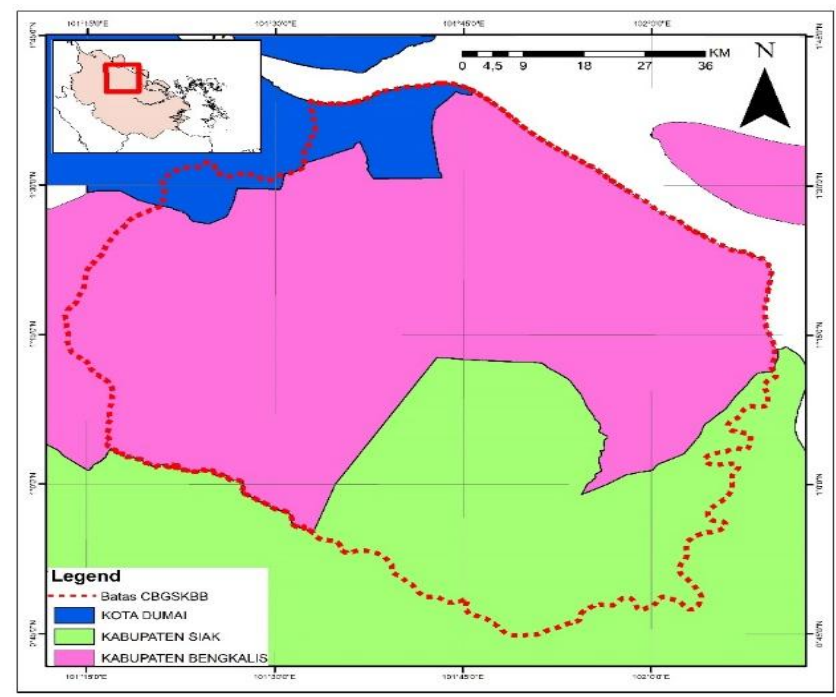

Figure 1: Location Map of Study Area

\section{Methodology}

The data used in this research are Landsat TM 5 satellite imagery data, Landsat OLI 8, Indonesian Earth Map, boundary map of the Giam Siak Kecil Biosphere Reserve Bukit Batu, map road network and population density maps. The data used are temporal data from 1999, 2009 and 2019. The software used in this research is ArcGIS 10.6, MS Excel 2020, and SPSS Statistics 24.

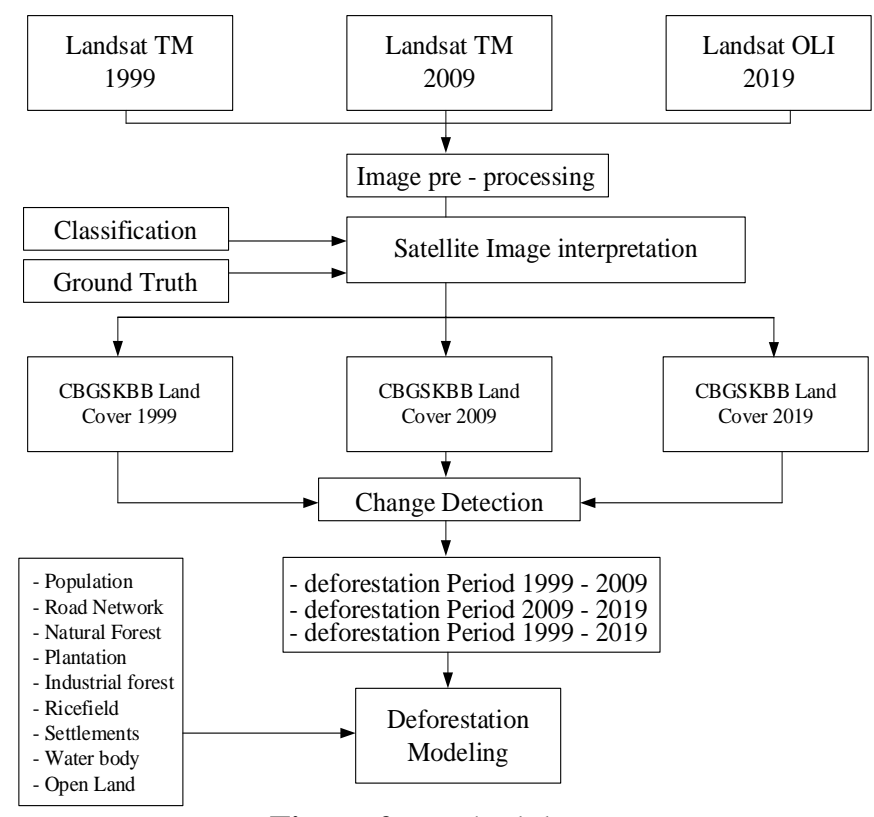

Figure 2: Methodology

\subsection{Land Cover Analysis}

Land cover analysis is carried out by interpretion data of Landsat image data. TM 5 in 1999, TM 5 landsat images in 2009 and OLI 8 landsat images in 2019. Image interpretation is carried out using the classification method. The classification method used is the guided Maximum Likelihood Classification classification, by making a training sample area comparing and calculating the average value of the diversity between classes and existing bands. The method is Maximum Likelihood Classification based on the same pixel value and image recognition. One characteristic with a normal distribution can represent each pixel in its class. The level of accuracy of the method Maximum Likelihood Classification has a high enough value [8].

$P(i \mid x)=\frac{p(i \mid x) P(i)}{P+(x)}$

Where:

$\mathrm{P}(\mathrm{i} \mid \mathrm{x})=$ The conditional probability of a class $\mathrm{i}$, which is calculated with the provision that the vector $x$ is unconditional.

$P(x \mid i)=$ The conditional probability of the vector $x$, which is computed with an unconditional class.

$\mathrm{P}$ (i). = The probability of a class $\mathrm{i}$ emerging from an image. $\mathrm{P}(\mathrm{x})=$ Probability of vector $\mathrm{x}$

\subsection{Deforestation Analysis}

Deforestation analysis was carried out using the results of the 1999, 2009 and 2019 land cover analysis. From the results of the analysis, the method was then carried out overlay with the aim of observing changes in land cover that occurred. The results of the overlay that have been carried out are then specified in the natural forest cover class other than natural forest which will be categorized as non - forest, so that it is known how much deforestation occurred in natural forests from 1999 - 2009, 2009 - 2019 and 1999 2019. The form of the overlay method is explained with the following equation [9].

$$
P(i \mid x)=\frac{p(i \mid x) P(i)}{P+(x)}
$$

Where:

$\mathrm{P}(\mathrm{i} \mid \mathrm{x})=$ The conditional probability of a class $\mathrm{i}$, which is calculated with the provision that the vector $\mathrm{x}$ is unconditional.

$\mathrm{P}(\mathrm{x} \mid \mathrm{i})=$ The conditional probability of the vector $\mathrm{x}$, which is computed with an unconditional class.

$\mathrm{P}(\mathrm{i}) .=$ The probability of a class $\mathrm{i}$ emerging from an image.

$\mathrm{P}(\mathrm{x})=$ Probability of vector $\mathrm{x}$

The next deforestation analysis is to calculate the annual rate of deforestation, the purpose of calculating the rate of deforestation is to determine the amount of deforestation which happens every year. The calculation of the deforestation rate is explained by the following equation [10].

$$
\mathrm{PTH}=\frac{(A 1-A 0)}{(T 1-T 0)}
$$


Where:

PTH = annual land cover change in a certain prode, expressed in area per year year $\left(\mathrm{Km}^{2} /\right.$ year $)$

$\mathrm{A} 0=$ land area at the time of initial observation

$\mathrm{A} 1=$ land area at the time of final observation

$\mathrm{T} 0=$ year of initial observation

$\mathrm{T} 1$ = year of final observation

\subsection{Spatial Modeling of Deforestation}

Spatial modeling of deforestation use multiple linear regression analysis techniques that explain the relationship of one dependent variable (Y) with two or more independent variables $(\mathrm{X} 1, \mathrm{X} 2, \ldots \mathrm{Xn})$. The purpose of multiple linear regression test is to predict the value of the dependent variable (Y) if the values of the independent variables $(\mathrm{X} 1, \mathrm{X} 2, \ldots, \mathrm{Xn})$ are known. In addition, it is also to find out how the direction of the relationship between the dependent variable and the independent variables is. The form of the multiple linear regression equation is as follows [11].

$\mathrm{Y}=\mathrm{a}+\mathrm{b}_{1} \mathrm{X}_{1}+\mathrm{b}_{2} \mathrm{X}_{2}+\ldots+\mathrm{b}_{\mathrm{n}} \mathrm{X}_{\mathrm{n}}$.

$\mathrm{Y}=$ dependent variable

$\mathrm{a}=$ constant

$\mathrm{b} 1, \mathrm{~b} 2, \ldots, \mathrm{bn}=$ regression coefficient value

$\mathrm{X} 1, \mathrm{X} 2, \ldots, \mathrm{Xn}=$ independent variable

Deforestation modeling analysis processes the results of calculations from the annual rate of change of land cover, population and accessibility from 1999 - 2019 The sample used in the modeling is in the form of time series data of 20 years and the smallest unit of analysis in the form of pixels is $30 \times 30$ meters of landsat image raster data. The variables used in this study are divided into two, including the dependent variable $(\mathrm{Y})$ and the independent variable $(\mathrm{X})$. Dependent variable (Y) in this study is deforestation (change in natural forest cover) and the independent variable $(\mathrm{X})$ is population density, road network, plantations, settlements, industrial plantation forests, water bodies, rice fields and open land area.

Table 1: Research Variable

\begin{tabular}{|c|c|c|}
\hline $\begin{array}{c}\text { Dependent } \\
\text { variable }(\mathrm{Y})\end{array}$ & $\begin{array}{l}\text { Independent } \\
\text { variable }(X)\end{array}$ & Sub Independent variable $(\mathrm{X})$ \\
\hline \multirow[b]{3}{*}{ Deforestation } & Population & - population density (soul/ $/ \mathrm{Km}^{2}$ ) \\
\hline & Accessibility & - Road network $\left(\mathrm{Km}^{2}\right)$ \\
\hline & $\begin{array}{c}\text { Land Cover } \\
\text { Change }\end{array}$ & $\begin{array}{l}\text { - Plantation }\left(\mathrm{Km}^{2}\right) \\
\text { - Settlements }\left(\mathrm{Km}^{2}\right) \\
\text { - Industrial Plantation Forest }\left(\mathrm{Km}^{2}\right) \\
\text { - Water Bodies }\left(\mathrm{Km}^{2}\right) \\
\text { - Rice Fields }\left(\mathrm{Km}^{2}\right) \\
\text { - Open Land }\left(\mathrm{Km}^{2}\right) \\
\end{array}$ \\
\hline
\end{tabular}

The variables in this study will then be tested related to relationship effect to deforestation. Testing the variables by formulating hypotheses on each variable. The form of the formulation of the hypothesis is divided into two, namely partial hypotheses and simultaneous hypotheses. The following is a modeling hypothesis for the deforestation of the Giam Siak Kecil - Bukit Batu Biosphere Reserve;

\section{Partial Hypothesis}

1) Industrial plantation forest (X1) has a significant effect on deforestation $(\mathrm{Y})$

2) Bushland (X2) has a significant effect on deforestation (Y)

3) Plantation (X3) has a significant effect on deforestation (Y)

4) Settlements (X4) have a significant effect on deforestation (Y)

5) Open land (X5) has a significant effect on deforestation (Y)

6) Rice fields (X6) have a significant effect on deforestation (Y)

7) Water bodies (X7) have a significant effect on deforestation (Y)

8) Road network (X8) significantly affects deforestation (Y)

9) Population (X9) significantly affects deforestation (Y)

\section{Simultaneous hypothesis}

Industrial plantation forest (X1), bushland (X2), plantations (X3), settlements (X4), open land (X5), rice fields (X6), water bodies (X7), road networks (X8) and population (X9) have a significant effect on deforestation (Y)

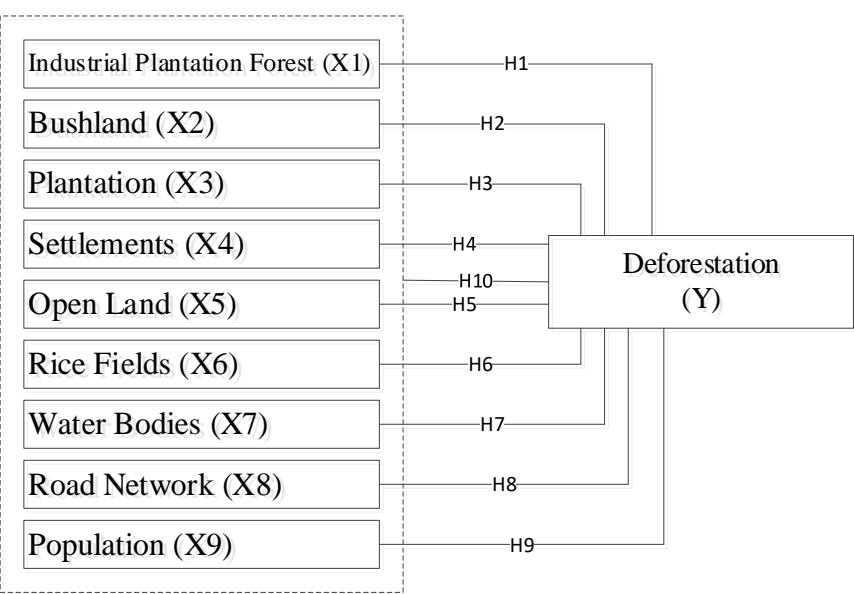

Figure 3: Hypothesis

In the final stage, namely testing the feasibility of the model from the formulation of the hypothesis. test criteria at a significance level of $0.05(5 \%)$ The following are the test criteria [12].

Hypothesis partially or $\mathrm{t}$ test (hypothesis 1, 2, 3, 4, 5, 6, 7, 8 and 9)

$\mathrm{H}_{0}=$ accepted if significant value $<0.05$ and $\mathrm{t}_{\text {count }} \mathrm{t}$ table

$\mathrm{H}_{0}=$ rejected if the value of significant $>0.05$ and tvalue $_{\text {arithmetic }}<$ ttable

Simultaneous hypothesis or F test (hypothesis 10)

$\mathrm{H}_{0}=$ accepted if significant value $<0.05$ and $\mathrm{F}$ value calculated $>$ F table

$\mathrm{H}_{0}=$ rejected if significant value $>0,05$ and theF value $_{\text {calculated }}<$ Ftable 


\section{Result}

\subsection{Land Cover Analysis}

The distribution of land cover in the Giam Siak Kecil
Biosphere Reserve, Bukit Batu, Riau Province consists of 8 land cover classes Obtained through landsat image classification

Table 2: Land Cover Classification

\begin{tabular}{|c|c|c|c|c|c|c|c|c|}
\hline \multicolumn{3}{|c|}{ Land Cover 1999 } & \multicolumn{3}{c|}{ Land Cover 2009 } & \multicolumn{3}{c|}{ Land Cover 2019 } \\
\hline Classification & $\mathrm{KM}^{2}$ & $\%$ & Classification & $\mathrm{KM}^{2}$ & $\%$ & Classification & $\mathrm{KM}^{2}$ & $\%$ \\
\hline Natural Forests & 4755,04 & $67,49 \%$ & Natural Forests & 2771,54 & $39,34 \%$ & Natural Forests & 1655,78 & $23,50 \%$ \\
\hline $\begin{array}{c}\text { Industrial } \\
\text { Plantation Forest }\end{array}$ & 85,21 & $1,21 \%$ & $\begin{array}{c}\text { Industrial } \\
\text { Plantation Forest }\end{array}$ & 844,21 & $11,98 \%$ & $\begin{array}{c}\text { Industrial } \\
\text { Plantation Forest }\end{array}$ & 1278,00 & $18,14 \%$ \\
\hline Bushland & 1329,11 & $18,86 \%$ & Bushland & 784,26 & $11,13 \%$ & Bushland & 552,57 & $7,84 \%$ \\
\hline Plantation & 402,67 & $5,72 \%$ & Plantation & 1374,40 & $19,51 \%$ & Plantation & 2905,11 & $41,23 \%$ \\
\hline settlement & 10,59 & $0,15 \%$ & Settlement & 23,59 & $0,33 \%$ & settlement & 38,11 & $0,54 \%$ \\
\hline Open land & 191,60 & $2,72 \%$ & Open land & 880,46 & $12,50 \%$ & Open land & 332,49 & $4,72 \%$ \\
\hline Rice Fields & 77,44 & $1,10 \%$ & Rice Fields & 182,86 & $2,60 \%$ & Rice Fields & 134,76 & $1,91 \%$ \\
\hline Water Bodies & 193,76 & $2,75 \%$ & Water Bodies & 184,11 & $2,61 \%$ & Water Bodies & 148,60 & $2,11 \%$ \\
\hline
\end{tabular}

The classification results show significant differences in the area of each land cover in the Giam Siak Kecil Biosphere Reserve area - Bukit Batu, especially in natural forest, which continues to decrease in terms of area or percentage, while on the other hand, land cover such as the meaning of plantations, industrial forest plantations, rice fields, and settlements experienced a significant increase in the period of 20 years, namely from $1999-2019$.

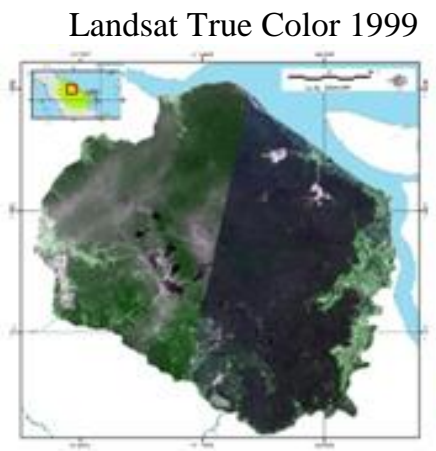

Landsat True Color 2009

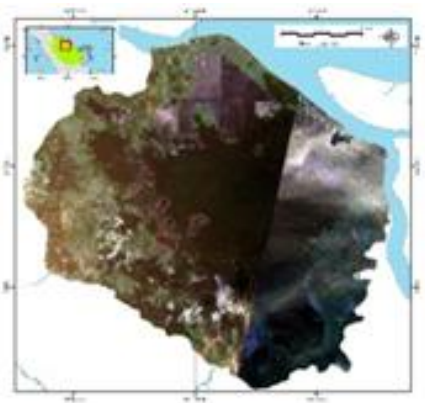

Landsat True Color 2019

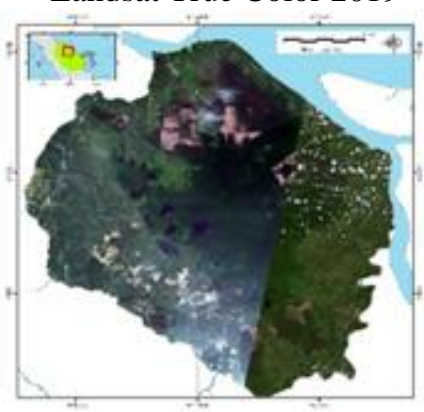

Figure 4: Land Cover Map
Land Cover 1999

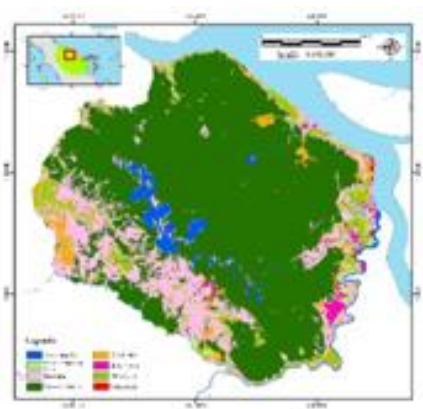

Land Cover 2009

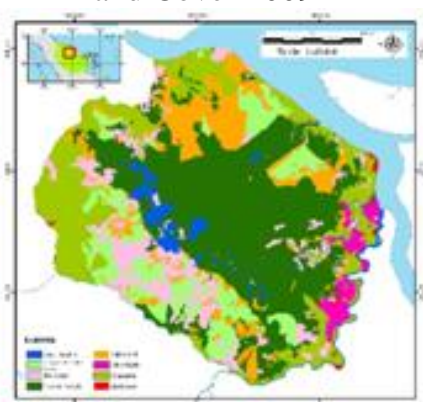

Land Cover 2019

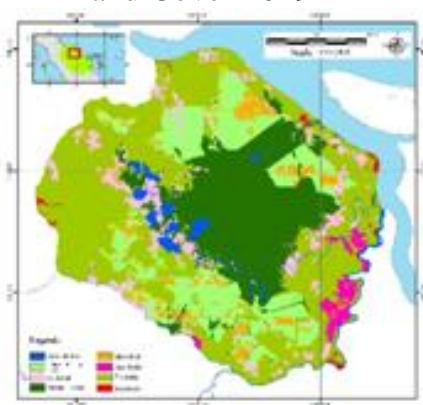

land cover in the Biosphere Reserve Giam Siak Kecil Bukit Batu includes natural forest, industrial plantation forest, bushland, plantations, settlements, vacant land, rice fields, and water bodies.

\subsection{Deforestation Analysis}

Deforestation analysis was carried out with overlay analysis or overlapping on land cover data of the Giam Siak Kecil Bukit Batu Biosphere Reserve, Riau Province. The focus on detecting deforestation is on natural forest cover classes thatare changing. Deforestation detection process is carried out by categorizing land cover classes in the form of forest areas including natural forests while non - forests include plantations, industrial plantation forests, rice fields, bushland, open land, settlements and water bodies.

Deforestation $1999-2009$

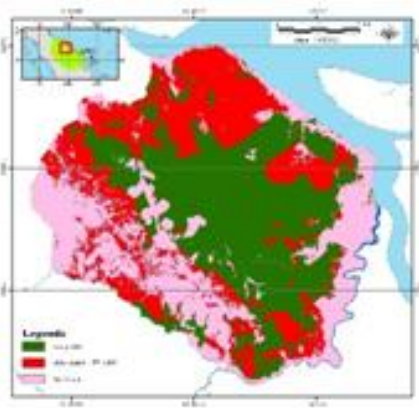

Deforestation 1999 - 2009

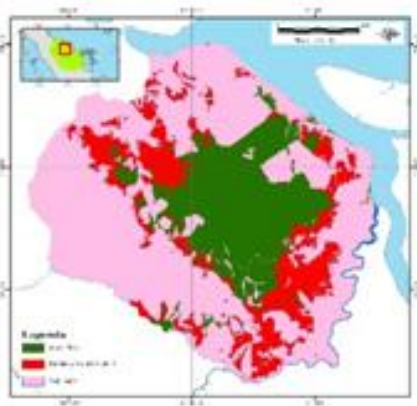

Deforestation 1999 - 2009

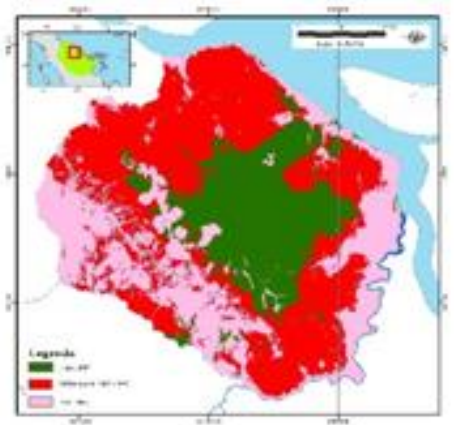

Figure 5: Deforestation Map 
Table 3: Deforestation

\begin{tabular}{|c|c|c|c|}
\hline Year & \multicolumn{2}{|c|}{ Land Cover $\left(\mathrm{KM}^{2}\right)$} & Deforestation (KM2) \\
\hline \multirow{3}{*}{1999} & Natural Forest & 4755,04 & Deforestation 1999 - 2009 \\
\cline { 2 - 3 } & Non Forest & 2290,38 & 1983, 50 \\
\cline { 2 - 3 } & Total & 7045,42 & \\
\hline \multirow{3}{*}{2009} & Natural Forest & 2771,54 & \multirow{2}{*}{ Deforestation 2009 - 2019 } \\
\cline { 2 - 3 } & Non Forest & 4273,88 & 1115,76 \\
\cline { 2 - 3 } & Total & 7045,42 & \\
\hline \multirow{3}{*}{2019} & Natural Forest & 1655,78 & Deforestation 1999 - 2019 \\
\cline { 2 - 3 } & Non Forest & 5389,64 & 3099,26 \\
\cline { 2 - 3 } & Total & 7045,42 & \\
\hline
\end{tabular}

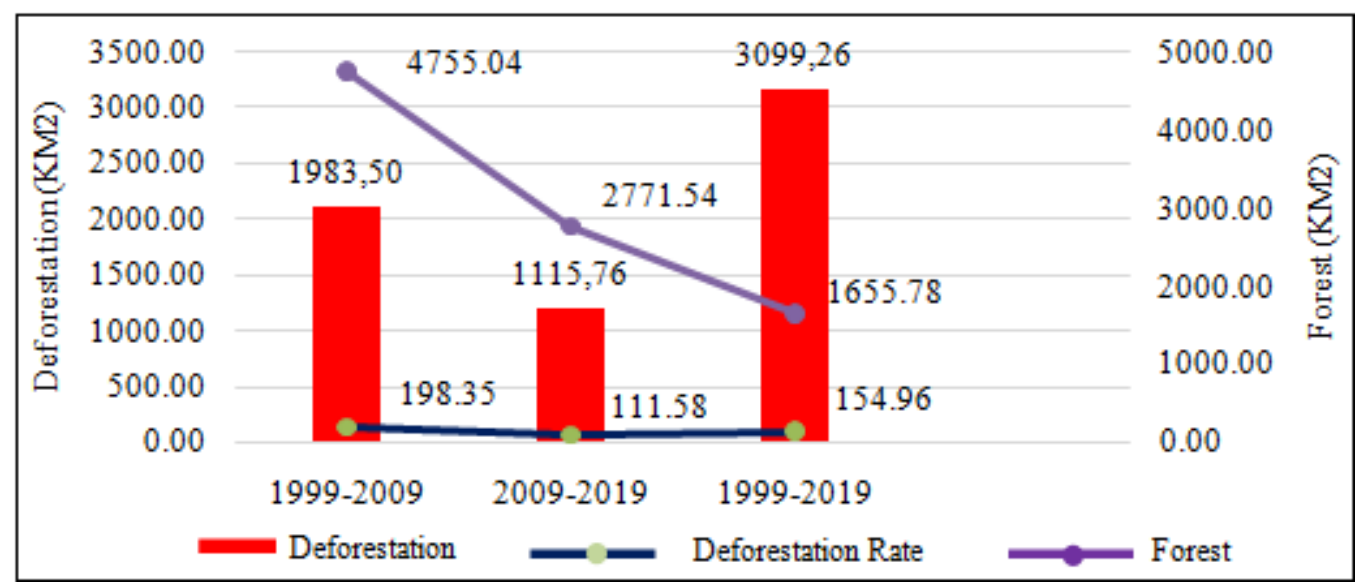

Figure 6: Chart of Deforestation

Based on the results of the analysis, it was overlay found that deforestation in the Giam Siak Kecil Bukit Batu Biosphere Reserve in the period 1999 to 2009 had deforestation of $1983.50 \mathrm{KM} 2$ with a deforestation rate of 198.35 KM2/year (4.17\% per year).). The period from 2009 to 2019 was $1115.76 \mathrm{KM} 2$ of deforestation with a deforestation rate of $111.58 \mathrm{KM} 2$ / year (4.03\% per year), so that for 20 years the forest area in the Giam Siak Kecil Bukit Batu Biosphere Reserve experienced deforestation of $3099.26 \mathrm{KM} 2$ with a deforestation rate of $154.96 \mathrm{KM} 2 /$ year or $3.26 \%$ per year.

\subsection{Spatial Modeling of Deforestation}

Permodelan Modeling of Deforestation Giam Siak Kecil Biosphere Reserve in Bukit Batu, Riau Province, was conducted to determine the contribution of land cover change to deforestation. The data processing model is based on the results of the analysis of land cover changes in the first research objective. The sample used is in the form of time series data of 20 years and the smallest unit of analysis in the form of pixels is $30 \times 30$ meters and the dependent variable $(\mathrm{Y})$ is deforestation and the independent variables are industrial forest plantations (X1), settlements (X2), plantations (X3), bushland (X4), open land (X5), rice fields (X6), water bodies (X7), road network (X8), population (X9).

Table 4: Descriptive Statistics

\begin{tabular}{|c|c|c|c|}
\hline Variabel & N & Minimum & Maximum \\
\hline Defosestation (Y) & 20 & 220389 & 3443626 \\
\hline Industrial Plantation Forest (X1) & 20 & 84333 & 1325319 \\
\hline Settlements (X2) & 20 & 1445 & 30575 \\
\hline Plantation (X3) & 20 & 144853 & 862823 \\
\hline
\end{tabular}

\begin{tabular}{|c|c|c|c|}
\hline Bushland (X4) & 20 & 107970 & 2780496 \\
\hline Open Land (X5) & 20 & 76540 & 765396 \\
\hline Rice Fields (X6) & 20 & 2145 & 50174 \\
\hline Water Bodies (X7) & 20 & 11713 & 117134 \\
\hline Road Network (X8) & 20 & 1915 & 67040 \\
\hline Population (X9) & 20 & 163 & 3058 \\
\hline Valid N (listwise) & 20 & & \\
\hline
\end{tabular}

F test results that explain information about the presence or absence of the influence of the independent variable on the dependent variable simultaneously. If the value of Sig. $<0.05$ and calculated $\mathrm{F}$ value $>\mathrm{F}$ table value, then there is a significant effect nilai $F$ tabel $=\alpha$ : df1/df2 df $1=\mathrm{K}-1 \mathrm{df} 2=\mathrm{N}-\mathrm{K}$

ket: $\mathrm{K}=$ number of variabel $\mathrm{N}=$ number of sampel nilai $\mathrm{F}$ table $=\mathrm{df} 1=10-1=9$

df $2=20-9=11$

Table 5: Distribution Table F $(0.05 / 5 \%)$

\begin{tabular}{|c|c|c|c|c|c|c|}
\hline $\begin{array}{l}\text { df1 } \\
\text { df2 }\end{array}$ & 4 & 5 & 6 & 7 & 8 & 9 \\
\hline 1 & 225 & 230 & 234 & 237 & 239 & 241 \\
\hline 2 & 19.25 & 19.30 & 19.33 & 19.35 & 19.37 & 19.38 \\
\hline 3 & 9.12 & 9.01 & 8.94 & 8.89 & 8.85 & 8.81 \\
\hline 4 & 6.39 & 6.26 & 6.16 & 6.09 & 6.04 & 6.00 \\
\hline 5 & 5.19 & 5.05 & 4.95 & 4.88 & 4.82 & 4.77 \\
\hline 6 & 4.53 & 4.39 & 4.28 & 4.21 & 4.15 & 4.10 \\
\hline 7 & 4.12 & 3.97 & 3.87 & 3.79 & 3.73 & 3.68 \\
\hline 8 & 3.84 & 3.69 & 3.58 & 3.50 & 3.44 & 3.39 \\
\hline 9 & 3.63 & 3.48 & 3.37 & 3.29 & 3.23 & 3.18 \\
\hline 10 & 3.48 & 3.33 & 3.22 & 3.14 & 3.07 & 3.02 \\
\hline 11 & 3.36 & 3.20 & 3.09 & 3.01 & 2.95 & 2.90 \\
\hline
\end{tabular}


Table 6: ANOVA

\begin{tabular}{|c|c|c|c|c|c|c|}
\hline \multicolumn{2}{|c|}{ Model } & Sum of Squares & df & Mean Square & F & Sig. \\
\hline \multirow{3}{*}{1} & Regression & 18200455630000.000 & 9 & 2022272848000.000 & 18.735 & $.000^{\mathrm{b}}$ \\
\cline { 2 - 7 } & Residual & 1079437342000.000 & 10 & 107943734200.000 & & \\
\cline { 2 - 6 } & Total & 19279892980000.000 & 19 & & & \\
\hline \multicolumn{7}{|c|}{ a. Dependent Variable: DDefosestation } \\
\hline \multirow{2}{*}{ b. Predictors: (Constant), Total Population, Plantations, Settlements, Open Land, Water Bodies, Rice Fields, } \\
Bushland, Road Networks, Industrial Plantation Forest \\
\hline
\end{tabular}

From the table above, it is known that the calculated $\mathrm{F}$ value (18.735) is greater than F table (2.90) and the value of Sig. in the table the value is $0.000<0.05$ so it can be concluded that the regression model estimated linearity is feasible to useadanya This explains the significant influence of the independent variables (industrial plantation forests (X1), Settlements (X2), Plantation (X3), Bushland (X4), Open Land (X5), Rice Fields (X6), Water bodies (X7), Road network (X8), and Total Population (X9)) simultaneously on the dependent variable (Deforestation (Y)).

The results of the $\mathrm{F}$ test that explain information about the presence or absence of the influence of the independent variable on the dependent variable simultaneously. If the value of Sig. $<0.05$ and calculated $F$ value $>F$ table value, then there is a significant effect of the independent variable on the dependent variable.

Value of $\mathrm{t}$ table $=\mathrm{t}(\alpha / 2 ; \mathrm{n}-\mathrm{k}-1)$ or $\mathrm{t}(0,05 / 2 ; 20-9-1)=$ $(0,025 ; 10)=2,228$

Table 7: Distribution Table t $(0.05 / 5 \%)$

\begin{tabular}{|c|c|c|c|c|}
\hline $\begin{array}{c}\text { Pr } \\
\text { df }\end{array}$ & 0.10 & 0.05 & 0.025 & 0.001 \\
\hline 1 & 3.07768 & 6.31375 & 12.70620 & 318.30884 \\
\hline 2 & 1.88562 & 2.91999 & 4.30265 & 22.32712 \\
\hline 3 & 1.63774 & 2.35336 & 3.18245 & 10.21453 \\
\hline 4 & 1.53321 & 2.13185 & 2.77645 & 7.17318 \\
\hline 5 & 1.47588 & 2.01505 & 2.57058 & 5.89343 \\
\hline 6 & 1.43976 & 1.94318 & 2.44691 & 5.20763 \\
\hline 7 & 1.41492 & 1.89458 & 2.36462 & 4.78529 \\
\hline 8 & 1.39682 & 1.85955 & 2.30600 & 4.50079 \\
\hline 9 & 1.38303 & 1.83311 & 2.26216 & 4.29681 \\
\hline 10 & 1.37218 & 1.81246 & 2.22814 & 4.14370 \\
\hline
\end{tabular}

Table 8: Coefficients

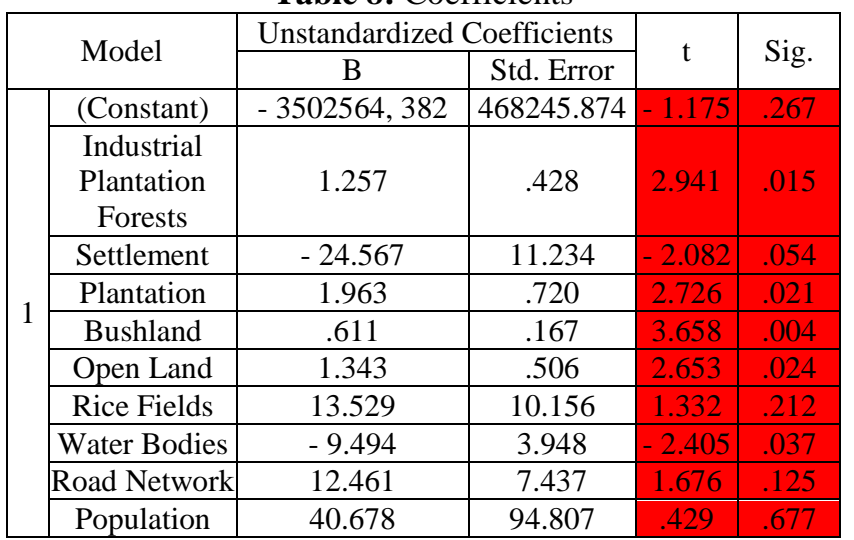

1) Value Sig. industrial plantation forests variable (X1) is $0.0150<0.05$ and the value of $\mathrm{t}$ count $(2.941)>\mathrm{t}$ table (2.228), then $\mathrm{H} 0$ is rejected and $\mathrm{H} 1$ is accepted. This means that there is a significant positive (directly proportional) effect between industrial plantation forests (X1) on Deforestation (Y). This explains that the higher the industrial plantation forests value, the higher the deforestation value will be. On the other hand, the lower the industrial plantation forests value, the lower the defosestasi value.

2) Value of Sig. Settlement variable (X2) is $0.054>0.05$ and the value of $\mathrm{t}$ count $(-2.082=2.082)<\mathrm{t}$ table (2.228), then H0 is accepted and H1 is rejected. This means that there is no significant effect between settlements (X2) on deforestation (Y).

3) Value of Sig. Plantation variable (X3) is $0.021<0.05$ and the value of $t$ count $(2.726)>t$ table (2.228), then $\mathrm{HO}$ is rejected and $\mathrm{H} 1$ is accepted. This means that there is a significant positive (directly proportional) effect between Plantations (X3) on Deforestation (Y). This explains that the higher the plantation value, the higher the deforestation value will be. On the other hand, the lower the plantation value, the lower the deforestation value.

4) ' Value of Sig. Bushland variable (X4) is $0.004<0.05$ and the value of $t$ count (3.658) $>\mathrm{t}$ table (2.228), then $\mathrm{H} 0$ is rejected and $\mathrm{H} 1$ is accepted. This means that there is a significant positive (directly proportional) effect between Settlements (X4) on Deforestation (Y). This explains that the higher the value of Bushland, the value of deforestation will also be higher or increase. On the other hand, the lower the Settlement value, the lower the Deforestation value or decrease.

5) Value of Sig. Open Land variable (X5) is $0.024<0.05$ and the value of $\mathrm{t}$ count (2.653) $>\mathrm{t}$ table (2.228), then $\mathrm{H} 0$ is rejected and $\mathrm{H} 1$ is accepted. This means that there is a significant positive (directly proportional) effect between Open Land (X5) on Deforestation (Y). This explains that the higher the value of Open Land, the value of Deforestation will also be higher or increase. On the other hand, the lower the value of Open Land, the lower the Deforestation value or decrease.

6) Value of Sig. Rice variable (X6) is $0.212>0.05$ and the value of $t$ count $(1,332)<\mathrm{t}$ table $(2.228)$, then $\mathrm{H} 0$ is accepted and $\mathrm{H} 1$ is rejected. This means that there is no significant effect between Rice Fields (X6) on Deforestation (Y).

7) Value of Sig. Water bodies variable (X7) is $0.037<0.05$ and the value of $\mathrm{t}$ count $(-2.405=|2.405|)>\mathrm{t}$ table (2.228), then H0 is rejected and H1 is accepted. This means that there is a significant negative (inversely proportional) effect between Water bodies (X7) on Deforestation (Y). This explains that the higher the value of the water body, the lower the deforestation value or decrease. On the other hand, the lower the value of the water body, the higher the deforestation value or increase.

8) Value of Sig. The road network variable (X8) is $0.125>$ 0.05 and the value of $t$ count $(1.676)<t$ table $(2.228)$, then $\mathrm{HO}$ is accepted and $\mathrm{H} 1$ is rejected. This means that there is no significant effect between the Road Network 
(X8) on Deforestation (Y).

9) Value of Sig. The population variable (X9) is 0.677 $<0.05$ and the value of $t$ count $(0.429)>t$ table (2.228), then $\mathrm{HO}$ is accepted and $\mathrm{H} 1$ is rejected. This means that there is no significant effect between the Total Population (X9) on Deforestation (Y).

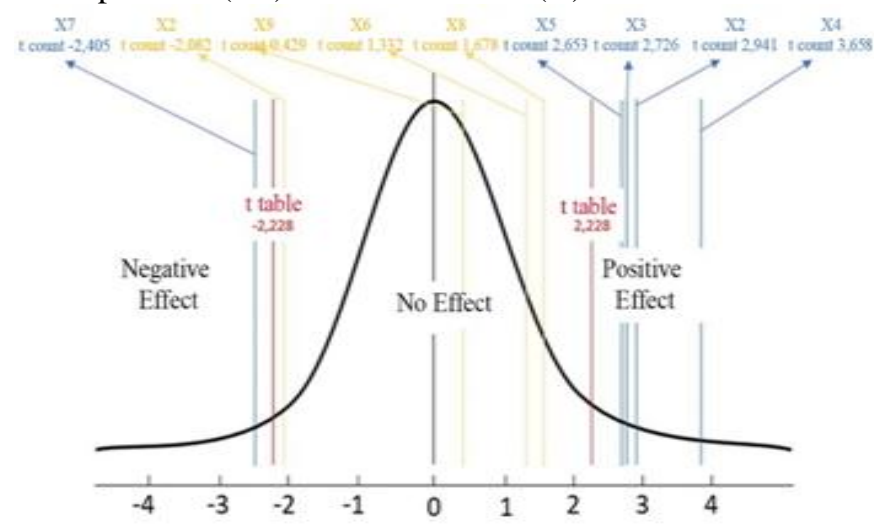

Figure 7: Bell - Curve Regression (t test)

The multiple linear regression equations in this study are: $\mathrm{Y}=-3502564,382+1,257(\mathrm{X} 1)+1,963(\mathrm{X3})+\mathbf{0 ,} 611$ $(\mathrm{X} 4)+1,343(\mathrm{X5})-9,494(\mathrm{X7})$

Defosestation $=-3502564,382+1,257$ (industrial plantation forests) + 1, 963 (Plantation) + 0, 611 (Scrub) + 1, 343 (Open Land) - 9, 494 (Body of Water)

Based on the above equation, it can be seen that of the 9 independent variables used in this study, there are 5 variables that are able to have an effect significant to defosestation of $-4.32 \mathrm{KM}^{2}$, every 1 change in value that occurs in the five variables. This means that for every additional 1 value of the independent variable (industrial plantation forests (X1), Plantation (X3), Bushland (X4), Open Land (X5), Water bodies (X7)), the Defosestation variable will experience a reduction of $-4.32 \mathrm{KM}^{2}$. On the other hand, for every 1 value reduction of the five independent variables, the defosestation variable will increase by $4.32 \mathrm{KM}^{2}$. In total, the amount of change given by all independent variables is $37.781 \mathrm{KM}^{2}$.

\section{Conclusion}

Changes in land cover in the Giam Siak Kecil Bukit Batu Biosphere Reserve in Riau Province in 1999, 2009 and 2019 experienced a significant increase, especially in natural forest areas which experienced a decrease in their cover area. The decrease in forest cover area is indicated by the increase in other land cover which continues to increase from its area. The area and rate of deforestation that occurred in 1999 - 2009 was $2116.05 \mathrm{~km}^{2}$ with a deforestation rate of $198.35 \mathrm{~km}^{2} /$ year, deforestation in 2009 - 2019 was 1187.57 with a deforestation rate of $111.58 \mathrm{~km}^{2}$ / year, and for 20 years the deforestation that occurred in 1999 - 2019 was 3166.97 with a deforestation rate of 154.96 $\mathrm{km}^{2} /$ year.

Based on the results of the modeling which aims to look at the variables that affect the occurrence of deforestation in the Giam Siak Kecil Bukit Batu biosphere reserve by partially and simultaneously answering the hypothesis, that the hypothesis that simultaneously all variables affect the occurrence of deforestation and the partial hypothesis that there are 5 variables of which, 4 variables have a significant effect positive and 1 variable has a negative effect. The variables that have a positive effect are Industrial plantations (X1), plantations (X3), bushland (X3), open land (X5) and the variable that has a negative effect is water bodies (X7).

\section{References}

[1] Ramdhoni, F., Fitriani, A. H., \& Afif, H. A. (2019). Identification of Deforestation through Land Cover Mapping in Banjar District, South Kalimantan. Seminar Nasional Geomatika, 3, 465. https: //doi. org/10.24895/sng.2018.3 - 0.987

[2] FWI. (2019). Angka Deforestasi Sebagai “ Alarm” Memburuknya Hutan. In Forest Watch Indonesia.

[3] Arif Margono, B. A., Turubanova, S., Zhuravleva, I., Potapov, P., Tyukavina, A., Baccini, A., Goetz, S., \& Hansen, M. C. (2012). Mapping and monitoring deforestation and forest degradation in Sumatra (Indonesia) using Landsat time series data sets from 1990 to 2010. Environmental Research Letters, 7 (3), 2000-2010. https: //doi. org/10.1088/1748 9326/7/3/034010

[4] Spatial Planning and Territory. (2018). Peraturan Daerah Provinsi Riau Nomor 10 Tahun 2018 Tentang Rencana Tata Ruang Wilayah Provinsi Riau Tahun 2018 - 2038 (Issue BAB VII Arahan Pemanfaatan Ruang Wilayah Provinsi).

[5] Sadili, A. (2016). Peat Forest on Siak Kecil Wildlife Sanctuary and PT Arara Abadi, Riau Province; Vegetation within of Damages. Jurnal Biologi Indonesia, 12 (1), 9-17.

[6] Febriani, I., Prasetyo, L. B., \& Dharmawan, A. H. (2017). Deforestation in Tahura Sekitar Tanjung Province Jambi. Journal of Natural Resources and Environmental Management, 7 (3), 195-203. https: //doi. org/10.29244/jpsl.7.3.195 - 203

[7] Farid, F. (2015). Book Remote Sensing.

[8] indrayanti jayanti. (2017). Perbandingan Metode Klasifikasi Maximum Likelihood dan Minimum Distance Pada Pemetaan Tutupan Lahan Di Kota Langsa. Tugas Akhir.

[9] Fadhli, R., Sugianto, S., \& Syakur, S. (2021). Analisis Perubahan Penutupan Lahan dan Potensi Karbon di Taman Hutan Raya Pocut Meurah Intan, Aceh Indonesia. Jurnal Ilmu Lingkungan, 19 (2), 450-458. https: //doi. org/10.14710/jil.19.2.450 - 458

[10] Dariono, D., Siregar, Y. I., \& Nofrizal, N. (2018). Analisis Spasial Deforestasi dan Degradasi Hutan di Suaka Margasatwa Kerumutan Provinsi Riau. Dinamika Lingkungan Indonesia, 5 (1), 27. https: //doi. org/10.31258/dli.5.1. p.27 - 33

[11] I Made Yuliara. (2016). Regresi linier berganda 1. http: //www.mendeley. com/research/regresi - linier berganda - $1 /$

[12] KNuryadi, Tutut Dewi Astuti, Endang Sri Utami, \& Martinus Budiantara. (2017). Dasar - Dasar Statistika Penelitian. http: //lppm. mercubuana - yogya. ac. id/wp - content/uploads/2017/05/Buku - Ajar_Dasar Dasar - Statistik - Penelitian. 